\title{
8
}

\section{Building executive capacity in the public service for better governance: The Philippine Civil Service ${ }^{1}$}

\section{Alex B. Brillantes Jr and Maricel T. Fernandez-Carag}

Leadership is the prime mover in bringing about alignment between capacity-building efforts of the public administration system and national development goals. Without effective and determined leadership, it is difficult to revitalise public administration in any country. While the importance of developing sound policy and institutional frameworks for revitalising public administration cannot be overemphasised, it is leadership that primarily drives the change process. (UN 2004: 2)

Investing in career executives in the civil service to develop and strengthen the leadership of the bureaucracy is critical. This is what Hooton (1997: xiii) calls 'executive governance', where the executives are at the 'heart of "permanent" government'. Politicians may come and go but the executive service officers remain at the helm of the bureaucracy. Hence, according to Stanton (2001: xvii), it is necessary

1 This chapter is adapted from a paper presented at the Taipei Conference on Building Executive Capacity in the Public Service for Better Governance, 31 October - 1 November 2011. We are grateful to Professor Tsai-Tsu Su, Professor John Wanna and James Low for the invitation to be part of this international conference. 
to make government manageable, which means that 'responsible government departments and agencies are expected to carry out their missions effectively and the public shall judge the results'.

Capacity development for career executive officers is necessary for responding to the demands of the public. Building the capacity of the public administration system is both a process and a goal (UN 2004). How the public sector is structured, how it operates and the role it performs within a country play an important part in economic and social progress. In particular, the quality of government leadership has a great impact on the quality of governance, which in turn affects a region's level of development. Reforming the public sector in both developed and developing countries is not an easy task and there are many difficulties to overcome. In the past 20 years, a number of national and international forces have contributed to significantly changing the role of the state, which has resulted in the need for new skills, attitudes and behaviours among public officials at all levels. In fact, the core competencies for the public sector of the twentyfirst century differ in many ways from those of the past, especially as the demands placed on public servants in terms of skills, knowledge and competency are rapidly increasing and becoming more complex. Top government leaders in developing countries are still facing old challenges while at the same time having to address new ones resulting from the many social, economic and political changes sweeping through the world (Bertucci, as cited in UNDESA 2005).

This chapter provides some historical context to the evolution of the Philippine Civil Service before focusing specifically on the Career Executive Service (CES) and the role of the Career Executive Service Board (CESB). It discusses the training and capacity development programs for career executive service officers (CESOs) and then identifies contemporary issues and concerns confronting the civil service in general, and building executive capacity in particular. 


\section{The Philippine Civil Service ${ }^{2}$}

The evolution and development of the civil service system of the Philippines must always be appreciated within its particular historical context. The Philippines has a long history of colonisation under Spain and the United States; as a result, its political and administrative systems were designed according to the style of its colonisers. The formal introduction of the civil service system occurred under US colonisation with the establishment of the Philippine Civil Service in 1900, as reflected in Act No. 5 (Civil Service Act), which also led to the establishment of the Bureau of Civil Service (BCS), with a mandate that the 'greatest care should be taken in the selection of officials for civil administration'. Since the Philippines attained political independence from the United States in 1946, various administrations have continued to reform the civil service - mostly through reorganisation interventions - with the general objective of achieving the classic three 'Es' of economy, efficiency and effectiveness. Over time, a fourth ' $E$ ' - that of equity - has been added.

There have been several highly significant pieces of legislation regarding the civil service in the Philippines, including former president Ferdinand Marcos's Presidential Decree Number 1 of 1972, declaring martial law, which reorganised the entire bureaucracy. The Administrative Code of 1987, issued by president Corazon Aquino through Executive Order 292, essentially reiterated existing principles and policies in the administration of the bureaucracy and for the first time recognised the right of government employees to self-organisation and to conduct collective negotiations under the framework of the 1987 Constitution. Today, efforts continue to further reform and strengthen the civil service, through the proposal of bills such as the omnibus Civil Service Code.

An interesting pattern in the politico-administrative system of the Philippines is that all administrations since 1946 have placed the reorganisation of the bureaucracy high on their agenda on their assumption of office. Among the more dramatic and visible reorganisations implemented were those by president Elpidio Quirino

2 For a detailed discussion of the Philippine Civil Service, please see Brillantes and Fernandez (2009). 
in the 1950s (through the Government Survey and Reorganisation Commission); by Marcos on the proclamation of martial law (Presidential Decree Number 1 establishing the Presidential Commission on Reorganisation and the implementation of the Integrated Reorganisation Plan); by Aquino in 1986 (the Reorganisation Plan of the Presidential Commission on Government Reorganisation); by president Fidel Ramos, who re-engineered and reinvented the bureaucracy in the late 1990s; by president Joseph Estrada, who established the Presidential Commission for Effective Governance; and finally, by president Gloria Macapagal-Arroyo, who introduced the rationalisation program.

The Philippine bureaucracy has essentially been shaped and influenced by its colonial heritage and legacies inherited from different political periods, each with its own administration and innovations. Now with more than 100 years of history, the civil service system continues to respond to the challenges and demands of nation-building and development, yet remains adversely affected by the political system of the country. Among the major contemporary initiatives of the civil service system is the formulation of a Civil Service Code that attempts to define a Philippine system resulting from and operating within the context of the Philippines' unique political, administrative and cultural history.

\section{Building executive capacity: The Career Executive Service ${ }^{3}$}

The CES constitutes the executive class in the Philippine Civil Service, which was formally introduced through Marcos's Integrated Reorganisation of 1972. This also led to the creation of the CESB in 1973, and it was during this time that the Career Executive Service Development Program (CESDP) was introduced to produce a corps of development executives who would carry out the development tasks of the 'new society' and create public understanding and acceptance of the CES as a new profession. The objective of continuously improving the quality of the civil service executive was promoted through

3 This section about the CES and CESB draws on the CESB website: www.cesboard.gov.ph. It also draws on Lodevico (n.d.). 
the implementation of a more competitive and stringent process in 1986. This was when Aquino had assumed the presidency and there was widespread reorganisation of the bureaucracy in which it was 'purged' of 1,000 civil servants including CESOs. However, the CES was reactivated in 1988. At present, there are roughly 6,260 positions within the CES - nine times more than three decades ago.

The chairperson of the CESB plays a key role in shaping the policy directions of the board. Table 8.1 reflects a list of the accomplishments of each CSB chair within the context of building executive capacity in the public service.

Table 8.1: Former chairpersons of the CESB and their accomplishments

\begin{tabular}{|l|l|}
\hline $\begin{array}{l}\text { Onofre D. Corpuz } \\
\text { (1973-78) }\end{array}$ & $\begin{array}{l}\text { Conceptualised the CES for the Philippines, drawing } \\
\text { from systems already in place in certain bureaucracies } \\
\text { around the world. His original concept of the CES as } \\
\text { a service that included all executives in government, } \\
\text { from assistant directors to undersecretaries, with ranks } \\
\text { designated by a number and characterised by mobility } \\
\text { in the service, continues today. }\end{array}$ \\
\hline $\begin{array}{l}\text { Jacobo C. Clave } \\
\text { (1978-81) }\end{array}$ & $\begin{array}{l}\text { Approved a performance evaluation system to } \\
\text { measure CESOs' significant contributions to national } \\
\text { development. }\end{array}$ \\
\hline $\begin{array}{l}\text { Armand V. Fabella } \\
\text { (1982-86) }\end{array}$ & $\begin{array}{l}\text { Focused on developing the managerial skills of CESOs } \\
\text { through the CESDP, a 10-month training program } \\
\text { run by the Development Academy of the Philippines. } \\
\text { This program included a 16-week residential training } \\
\text { course and a two-week barrio (village) immersion } \\
\text { program. It was crafted to develop camaraderie among } \\
\text { the participants to enable them to establish lasting } \\
\text { networks cutting across the bureaucracy. }\end{array}$ \\
\hline $\begin{array}{l}\text { Patricia A. Sto. Tomas } \\
\text { (1988-95) }\end{array}$ & $\begin{array}{l}\text { Initiated the shift from a training-based to an } \\
\text { examination-based system for the acquisition of CES } \\
\text { eligibility and rank, which broadened the base from } \\
\text { which eligible candidates and CESOs were sourced. } \\
\text { The examination-based system ensured two features } \\
\text { of a good recruitment system: open competition and } \\
\text { intense selection. This shift to an examination-based } \\
\text { system was complemented by the inclusion of shorter } \\
\text { training courses focusing on leadership, values, } \\
\text { interpersonal relations and administrative efficiency. }\end{array}$ \\
\hline $\begin{array}{l}\text { Amado Luis S. Lagdameo Jr } \\
\text { (1995) }\end{array}$ & $\begin{array}{l}\text { Short term as chairperson. Transition from the integration } \\
\text { of CESB to CSC' and then nullification of the integration } \\
\text { in 1995. }\end{array}$ \\
\hline
\end{tabular}




\begin{tabular}{|l|l|}
\hline $\begin{array}{l}\text { Corazon Alma G. De Leon } \\
\text { (1995-2001) }\end{array}$ & $\begin{array}{l}\text { Established the CES eligibility requirement for } \\
\text { appointment to third-level positions in the CSC. This } \\
\text { requirement was created to assist the CESB in coping } \\
\text { with the growing number of government executives } \\
\text { seeking third-level eligibility. }\end{array}$ \\
\hline $\begin{array}{l}\text { Karina Constantino-David } \\
\text { (2001 - February 2008) }\end{array}$ & $\begin{array}{l}\text { Unified the third-level eligibility requirements given by } \\
\text { the CESB and the CSC. Essential to this achievement } \\
\text { was the clarification of the concept of the third level and } \\
\text { its adaptation to existing realities and current limitations } \\
\text { of law. A new instrument for the Career Executive } \\
\text { Service Performance Evaluation System was also } \\
\text { crafted and rolled out. }\end{array}$ \\
\hline $\begin{array}{l}\text { Bernardo P. Abesamis } \\
\text { (March 2008 - present) }\end{array}$ & $\begin{array}{l}\text { Pursued an integrated CES human resource } \\
\text { development framework through the implementation } \\
\text { of the Continuing Professional Development Program } \\
\text { based on the CES Competency Grid developed in 2008. }\end{array}$ \\
\hline
\end{tabular}

${ }^{1} \mathrm{CSC}=$ Civil Service Commission

Source: CESB website (www.cesboard.gov.ph).

In keeping with its mandate to form not only well-selected but also development-oriented officials, the CESB designed a shorter threepronged core training program called the Executive Leadership Program (ELP) for its CESOs and those eligible for CES, commonly known as 'CESO eligibles'. The ELP was launched in 1993 and was shorter than earlier training programs in the CES. It was made up of three separate modules: Salamin, Diwa and Gabay. Since it was piloted in 1993, the ELP has produced 1,257 graduates. In a bold move in 2002, the CESB adopted a revised policy (CESB Resolution No. 453) on original and promotional appointments to CES ranks. This policy provides for the appointment of CES eligibles initially to Rank VI regardless of their position, and for the CESOs to work their way up to a higher rank without necessarily being promoted to a higher position, through demonstrated competence, sustained performance levels, completion of prescribed training programs in the CES and passing a screening process for promotion to Rank III and higher. To ensure rigorous selection, the present CESB also restored the Assessment Centre to the CESO promotion process for those who pass the Management Aptitude Test Battery (MATB). This was the case in the early 1990s.

For more than a decade to 1985 , the route to CES eligibility and a CESO rank was via a training program; however, the CESB shifted from a training-based to an examination-based selection system 
in 1989. The new four-stage examination system based on merit and open competition enabled the institution to speed up the process of granting eligibility while ensuring that high standards for selection were met. In 1990 the CESB conducted a nationwide MATB on more than 1,000 applicants from both the government and the private sector. For the first two years, the MATB was conducted only once a year. By 1994 it was conducted twice a year and by 2000 it was conducted on a monthly basis in addition to the two annual rounds. Today the MATB is conducted in the 12 regions of the Philippines on a monthly basis, and, nationwide, bi-annually. After 1990, the CESB also adopted other methods by which officials could acquire CES eligibility and rank, including the testimonial eligibility route, accreditation of the Executive Leadership Management (ELM) Program and accepting the Master of National Security Administration (MNSA) and Master of Public Safety Administration (MPSA) courses as equivalent to passing some stages of the four-stage screening process. The testimonial eligibility route has since been suspended (Lodevico n.d.)

\section{Designing, implementing and sustaining programs to build executive capacity}

In the Philippines, the CES is the 'third level' or managerial class of career positions. Created by Presidential Decree No. 1 to 'form a continuing pool of well-selected and development-oriented career administrators who shall provide competent and faithful service', ${ }^{4}$ it is the highest level of career civil service as determined in the Position Classification and Compensation System. The CES is also a public personnel system separate from that of the first two levels in the Philippine Civil Service. The first level includes clerical, trades, crafts and custodial positions whether in non-supervisory or supervisory capacities; and the second level comprises professional, highly technical, scientific or other highly specialised positions in a supervisory or non-supervisory capacity requiring at least a bachelor degree or equivalent as determined by the Civil Service Commission (CSC). The CES operates on the 'rank concept'. CESOs are appointed

4 This was the first Presidential Decree: PD No. 1 issued by former President Ferdinand Marcos on 24 September 1972 after declaration of Martial law on 21 September 1972 for the establishment of the Career Executive Service. 
to ranks and assigned to CES positions; hence, they may be reassigned or transferred from one CES position to another and from one office to another but not more than once every two years. In this respect, the CES is like the armed forces and the foreign service, in which officers are also appointed to ranks and assigned to positions. Positions in the CES are the career positions above the level of division chief staff who exercise managerial functions. Table 8.2 shows the aforementioned positions.

Table 8.2: Positions in the Career Executive Service

\begin{tabular}{|l|}
\hline Undersecretary \\
\hline Assistant Secretary \\
\hline Bureau Director \\
\hline Bureau Assistant Director \\
\hline Regional Director \\
\hline Assistant Regional Director \\
\hline Department Service Chief \\
\hline Other executive positions of equivalent rank as identified by the CESB \\
\hline
\end{tabular}

Source: CESB website (www.cesboard.gov.ph).

\section{The CESB}

The CESB is the governing body of the CES. It is mandated to promulgate rules, standards and procedures on the selection, classification, compensation and career development of members of the CES. The CESB comprises eight members: the chairperson of the CSC and the president of the Development Academy of the Philippines (DAP) as ex officio members, and six others appointed by the President of the Philippines for a term of six years. Day-to-day operations are handled by the CESB Secretariat, headed by an executive director and a deputy executive director. Five operating divisions are tasked to handle specific program areas.

To be part of the CES, the aspiring candidate must undergo the CES eligibility examination process, which has four stages: 1) written examination; 2) assessment centre; 3) performance validation; and 4) board interview. 
If the candidate is conferred CES eligibility and complies with the other requirements prescribed by the CESB, his or her name is then included on the roster of CES eligible candidates. He or she may then be assigned any CES position and appointed to a CES rank by the president on the recommendation of the CESB and will then become a member of the CES. Table 8.3 indicates the six CESO ranks in the CES ranking structure, with CESO I the highest rank (with an equivalent salary grade of 30 ) and CESO VI the lowest (with an equivalent salary grade of 25).

Table 8.3: CES ranking structure

\begin{tabular}{|l|l|}
\hline CESO rank & Salary grade \\
\hline CESO Rank I & SG 30 \\
\hline CESO Rank II & SG 29 \\
\hline CESO Rank III & SG 28 \\
\hline CESO Rank IV & SG 27 \\
\hline CESO Rank V & SG 26 \\
\hline CESO Rank VI & SG 25 \\
\hline
\end{tabular}

Source: CESB website (www.cesboard.gov.ph).

\section{Training and career development program for CESOs}

A crucial CESB program is training and career development for CESOs. The CESB, through Board Resolution No. 812 of 17 August 2009, approved and promulgated the Omnibus Rules, Guidelines and Standards on the Continuing Professional Development System for the Career Executive Service (CPDS-CES). The CPDS-CES serves as the overarching framework of policies, rules and standards for the development, implementation and evaluation of all capacity-building programs to be offered for the career and professional development of CESOs and CESO eligibles in the civil service.

These capacity-building programs include training and career development programs based on the need for CESOs who are not only good managers but also effective leaders. The CESB has lined up a number of training and other career development interventions to provide a range of experiences, knowledge and skills necessary for 
effective job performance. Career development in the CES follows a framework that responds to the CES officials' career development needs from the time they enter the CES up to preparations for retirement from the service. Thus, it aims to complete their 'whole person development' as a CESO.

CESB training programs are designed to improve the competency not only of CESOs but also of the third-level eligible candidates, to nurture in them a deeper sense of commitment to public service and to help them understand the CES as a program of government, a culture and a way of life. However, in the case of third-level eligible candidates, only those occupying at least a division chief position or its equivalent, unless otherwise provided, may participate in the training and human resource development programs of the CESB. These programs include Executive Leadership Program courses and CESB-accredited training courses.

\section{Executive Leadership Program}

The ELP is currently the foundational training program for CESOs and CEO eligibles. It includes three courses corresponding with a three-pronged leadership and management framework of: 'knowing one's self' (SalaminngPaglilingkod or Salamin), 'relating to others' (DiwangPaglilingkod or Diwa) and 'leading the organisation' (GabayngPaglilingkod or Gabay). The program also includes the Community-Organisational Attachment Module (COAM), a learning integration course.

\section{SalaminngPaglilingkod (Salamin)}

Salamin, a course on self-examination, is anchored on the premise that the best leaders are those who have a good understanding of themselves, their values and their leadership style. Learning modules are built around, and have the objective of, enhancing the identified Competency Standards for CESOs.

The learning outcomes of Salamin include making participants:

- reflect on their values given their primary roles as family members, members of the community and government executives

- examine the leadership requirements of the bureaucracy and their organisations and how they fit into these 
- relearn the struggles and aspirations of the common people towards increased responsiveness in government policies and programs

- from this experience, articulate and refine their values and leadership style and gain a renewed commitment to public service.

\section{DiwangPaglilingkod (Diwa)}

Diwa, a course on interpersonal relations, is based on the premise that good leaders are those who have a deep understanding and appreciation of how they and other people inside and outside the organisation influence each other in their behaviour and interpersonal relations. It emphasises participatory management and effective teamwork in achieving organisational goals and objectives. It also aims to address how to deal with the public and other stakeholders more effectivelyone of the main concerns of executives - as well as how to deliver the highest service possible. Learning outcomes of Diwa are aimed at eliciting productive behaviour from subordinates and teams to achieve public service excellence and to positively influence the behaviour of superiors and peers for cooperation and support.

\section{GabayngPaglilingkod (Gabay)}

Gabay provides learning modules aimed at addressing the executive's need to remain effective on the job and to impart a deeper appreciation of government policies and programs. It seeks to provide:

- enhanced awareness and greater appreciation of the demands and challenges facing a public manager

- a wider perspective on the environment of public management around which leadership and managerial responsibilities are exercised

- familiarity with the planning and organisational processes and the information and communication technology (ICT) governance and management concepts that are essential in the development of organisations

- additional knowledge on how to optimise government administrative support systems for effective decision-making and management. 
Gabay also exposes participants to a community organisation that enables the sharing of competencies, insights and managerial experiences and the ability to work on governance and development concerns with local officials, civil society and community stakeholders.

\section{COAM (Community-Organisational Attachment Module)}

COAM is the final module of the ELP. Together with the Salamin, Diwa and Gabay modules, it aims to:

- widen the scope of, increase and strengthen the key leadership and managerial competencies of career executives via real-life and structured immersion in a community organisation

- foster an environment and cultivate partnerships for learning where executives can share their competencies, insights and experiences in managing organisations and work on governance and development challenges and imperatives with local government officials, civil society and private sector leaders and other community stakeholders

- encourage executives to individually and collectively explore, adopt and advocate meaningful, innovative and results-focused approaches for re-examining governance and leading reforms in the public sector.

\section{CESB-accredited training programs}

The CESB is not the only agency that designs and implements executive development programs for the civil service; other agencies also have their own custom-made programs. To complement CESB learning activities and provide CES executives with a further continuing executive development program, the CESB works in partnership with reputable training institutions to offer programs that address specific leadership and managerial competencies.

Descriptions provided by the relevant training institutions appear in a modified form below.

\section{Communicating Change through Media}

This is a two-day seminar provided by Blas F. Ople Policy Centre and Training Institute with workshops designed to equip participants with the knowledge and skills needed to communicate using the 
media in a fast-paced and evolving environment. CESOs, as policy advocates of government programs and services, play key roles in promoting messages of positive change and good governance. They must be adept in public diplomacy and skilful in the art of public communications to build networks of support within and beyond traditional constituencies. The seminar introduces concepts and best practices regarding the online marketing of government programs and services.

\section{Seven Habits: Applications for Managers Workshop}

This is an intensive hands-on, two-day workshop run by the Centre for Leadership and Change. It helps participants build a strong cadre of leaders capable of leading with character and competence. Managers and leaders learn to define their contributions, develop greater influence, leverage hidden resources, give constructive feedback and unleash the full potential of their team against critical priorities. This workshop is designed to help CESOs enhance desired behaviours learned in Salamin, Diwa and Gabay sessions.

\section{Power Principle Workshop}

This workshop helps CESOs develop desired competencies for leading in a continuously changing environment and for networking for productive partnerships. It teaches participants a new paradigm of power: the 'principle-centred power' - the ability to influence others' behaviour rather than to control, change or manipulate it. The Centre for Leadership and Change provides this workshop.

\section{Leadership: Great Leaders, Great Teams, Great Results}

This is another training course provided by the Centre for Leadership and Change. It provides participants with the mindset and tools to execute CES core competencies and help them as leaders discover how to inspire trust and build credibility with people, define a clear and compelling purpose, create and align systems of success, unleash the talents and energy of a winning team and align the essential systems of execution, core work processes and customer feedback. 


\section{Change Leadership}

This is a practical course provided by Human Resource Innovations and Solutions (HURIS) on managing and handling the constant stream of changes in today's complex world. This two-day program includes research on individual and organisational change dynamics and hands-on exposure to practical change leadership tools and practices.

\section{Managerial Leadership}

This is another training program run by HURIS, which goes beyond the basics of planning, organisation and leadership for results by highlighting, through experiential insights, the core underlying principles of these fundamental managerial practices. The program is based on real cases and covers the latest research and best practices, and the participants gain a wide and practical perspective of managerial tasks and leadership responsibilities.

\section{Performance and Results Management}

This course provides participants with the opportunity to master the skills of managing employee performance and building a resultsfocused work culture through coaching. It covers the skill areas of crafting behavioural goals, selecting predictive metrics of performance and motivating people to produce consistent results. Learning is stimulated through a combination of research-based lectures, roleplaying, management simulations and film clips.

\section{Strategic Thinking}

This course deals with a comprehensive overview of strategic thinking skills including systems thinking, critical reasoning and creativity. Through an interactive and engaging mix of presentations, roleplaying and management simulation exercises, participants acquire insights and skills on improving their grasp of strategy formulation and strategic learning.

\section{The New Leadership Style for the Twenty-First Century}

Peter Drucker predicted that the leader of the future will be one who asks while the leader of the past is one who tells. This course seeks to present the secrets to becoming a successful leader in the twenty- 
first century. Focused on self-mastery and emotional intelligence, participants practise coaching, conflict management and handling difficult employees.

\section{Policy Appreciation Course}

This three-day program provided by the DAP is aimed at equipping senior CESOs with the requisite concepts and skills to be effective producers and consumers of policy analysis. The course guides senior CESOs and their principals not only to make informed policy choices but also to implement these choices in the public interest. Specifically, the course enables participants to be more aware of the value of policy analysis and of the role policy plays in shaping the activities of government. Participants better understand the theoretical underpinnings and components of policy analysis, the range of policy tools and techniques as well as the process that must be followed and the conditions that must be met to ensure the quality and feasibility of policy outcomes. They also develop an understanding of how the policymaking process applies to practical situations; indicate where to find policy-related methodological resources and information; realise or situate their role as CESOs in the entire policy process; and reflect together on the role each institution can play in sound policymaking.

\section{Creative Innovations and Reforms for Committed Leadership and Effectiveness (CIRCLE) Forum Series}

This is a series of monthly, multi-sectoral forums conducted nationwide, showcasing exemplary, pioneering and influential leaders from the CES and various fields of governance and development, who interact with government executives in interactive learning experiences while dissecting important issues relating to governance and development. These leaders distil and share their insights and practical know-how in achieving strategic institutional and sectoral outcomes and in realising their personal and professional goals while confronting dayto-day executive challenges. This is a major professional development program of the CES Career Development and Life-Long Learning Strategic Framework, and an executive who attends and completes it earns credit points. It also promotes the CESB's core objective of providing meaningful, innovative and effective mechanisms for: 
- the personal and professional development of members of the CES

- strengthening strategic networks and engagements with key sectors who share the same mission of improving governance, managing partnerships and promoting development and change.

\section{CES Executive Leadership and Wellness Camps}

These camps are part of the CESB's advocacy to promote total wellness, work-life balance and sustained productivity among government executives. They include:

- learning activities on maintaining relationships and a healthy lifestyle

- sessions to enhance longevity and increase productivity at work

- holistic stress management that deals not only with physical and emotional but also spiritual and social wellbeing aspects.

Follow-up sessions are also conducted to equip participants with further motivation, knowledge and practical tips.

\section{CES Thought Leadership Congress}

The CES Thought Leadership Congress (CES-TLC) is a thematic and scholarly forum showcasing pioneering and influential citizen leaders from the Philippines and other nations who have made valuable and enduring contributions in various disciplines. This program immerses government executives in hands-on, face-to-face and life-based learning encounters with these champions, exemplars and luminaries, who distil their ideas and insights; impart their wisdom and inspiration; and share their visions and stories of struggle, discovery and hope. It is planned and regularly conducted by the CESB in cooperation with its partner institutions as a whole-day symposium every semester in metropolitan Manila and in different regional capitals.

\section{CES Leader's Enterprise Attachment Program}

The CES Leader's Enterprise Attachment Program(LEAP) is a structured immersion-attachment program open to all CESOs and eligible candidates of good standing in the CES. The program exposes these public sector executives to new organisations and work environments in carefully selected private sector enterprises. In partnership with the chosen enterprise, the CESB facilitates the immersion attachment with 
the professional guidance of an enterprise-based volunteer mentor (or 'learning partner') within a fixed period, linking the private and public sectors in developmental synergy. The program builds a dynamic learning environment by partnering career executives and managers from both sectors in the creation and application of knowledge, skills and new technologies; in sharing insights and experiences; and in jointly addressing vital corporate governance problems and issues. As a key element in the vision of a strengthened CES, LEAP's primary goals are improved levels and quality of productivity-primarily demonstrated in high-value, efficient and sustained levels and quality of work performance achieved by developing and institutionalising vital technical competencies among CESOs and eligible candidates, resulting in optimal organisational effectiveness. Leading to these goals are the upgrading of competencies and nurturing key leadership and managerial competencies of career executives through structured immersion at (or 'attachment' with) model institutions.

\section{CES Management Apprenticeship Program}

The CES Management Apprenticeship Program (MAP) is a twoyear, government-wide, on-the-job and multi-modal leadership and managerial capability development program that prepares third-level eligible candidates for entry into the CES. The program incorporates the development, implementation and monitoring of standardised inservice immersion modules by the CESB in partnership with various government agencies, clustered into sectors. These modules, which candidates are required to undergo, include:

- MAP Foundation Course Series (MAP-FCS)

- MAP Continuing Professional Education Program (MAP-CPEP)

- corporate policymaking and strategic planning activities

- international study visits, exchange programs, conferences and other overseas professional development activities

- fixed-term cross-sectoral postings in the government sector

- the formulation of the MAP Terminal Report.

The completion credits earned are considered partial fulfilment of prerequisites for a third-level eligible candidate to qualify for CESB endorsement for initial appointment to a CES rank. 


\section{CES Fellows Program}

This is a development-oriented off-site learning program that seeks to provide opportunities for CESOs to explore new avenues and apply tools for their career development while working on leadership and governance challenges outside the agency work environment. It is designed primarily to strengthen CESO core professional competencies and improve their executive performance. It is a management intervention granted as a reward or privilege, which allows CESOs to engage in external development work (with pay) as an alternative to the performance of regular/standard office functions. CES Fellows have the option of working as volunteers, development facilitators, technical experts or consultants, educators, program/project managers or coordinators, or in other roles in various fields. CES Fellows work on a part-time or full-time basis through postings ('attachments') to:

- selected organisations and institutions, whether local or international

- other government agencies

- local governments

- non-governmental or community-based organisations either in the Philippines or in another developing country.

Fellows may also engage in self-initiated or existing institutional or academic-based development work on strategic and urgent socioeconomic or ecological development issues.

\section{Executive Placement Program}

This program is designed to promote the placement of CESOs and CESO eligibles in CES positions. It is classified under two major subprograms.

- Executive Placement Program: This aims to match the placement participants' career options with the needs of the bureaucracy as determined by the agencies and/or the Office of the President Search Committee. It requires strategic and continuing partnership with the agency and gathering and maintenance of information regarding agency-specific requirements and the expertise and career options of the placement participants to enable job matching. 
- Placement Assistance and Referral Program: This aims to assist CESOs and eligible candidates requesting short-term or one-time endorsement.

\section{Performance management}

The performance of CES officials is evaluated annually through the CES Performance Evaluation System (CESPES) developed and administered by the CESB and installed in all departments and agencies as part of the performance management system focusing on third-level executives. It was developed to reflect the significance of the third level (which numerically represents only 1 per cent of the entire bureaucracy) as the determining factor of the quality and type of service that the rest of the bureaucracy offers to the public.

Like its predecessor, the CESPES measures the accomplishments of CESOs using the Performance Contract (PC), as well as their behavioural competence using the Behavioural Competency Scale. Accomplishments (referred to as milestones) are classed as either 'leading and innovating' or 'regular or routine'. Leading and Innovating (LI) milestones are policies, programs, projects or procedures that the CESOs create for the department or agency. They are innovations and reforms that aim to improve the quality of the department's or agency's structures, operations and resources. They are 'value-adding' measures that are developed and implemented within a given period - with a definite start and end. In contrast, Regular or Routine (RR) milestones are the outputs of functions or activities within the accountability of and performed by CESOs on a regular basis in the work setting. These may include outputs resulting from the performance of technical and administrative functions needed to sustain day-to-day operations in an office. The percentage of LI to RR milestones depends on the rank of the CES officials and is determined by the department or agency: the higher the position level, the higher the LI. CES officials are encouraged and expected to perform increasingly more innovative functions as their position level increases. This, to a degree, describes and justifies why they deserve the status and salary received.

A superior rates CESOs on the basis of their accomplishments using a scale of one to seven: 
1. unacceptable

2. below average

3. solid performance

4. good solid performance

5. above average

6. commendable

7. exceptional.

Superiors and subordinates alike rate CESOs on the basis of their behavioural competence using the Superior and Subordinate Rating Forms of the Behavioural Competency Scale, respectively. They are given a questionnaire of 30 statements indicating the attributes of government executives. They then rate CESOs according to how often these qualities are observed - again, using a scale of one to seven, with one being 'never' and seven being 'always'.

\section{The role of the NUCESO}

The energies and potential of graduates of the CES Program are harnessed through the National Union of Career Executive Service Officers (NUCESO). CESOs are treated to a variety of interventions designed to promote effective networking and greater camaraderie, as this is seen to have a positive effect on government programs. The NUCESO was formed when two CES organisations (the National Council of CES Organizations, NCCESO, and the ELP Alumni Association) merged. It aims to:

- keep alive and dynamic the ideals and purposes of the CES

- enhance the competencies of CESOs as public managers and leaders and encourage them to advocate programs for their agencies and communities in the pursuit of CES objectives

- promote and strengthen camaraderie between and among the CESOs in government

- extend assistance to individual CESOs in the recognition and protection of their rights as career executives

- provide a forum for discussion and resolution of issues concerning the national interest 
- implement projects that will contribute to the achievement of government goals

- not engage in any government unionism.

\section{Issues, gaps and challenges in career service and executive development ${ }^{5}$}

The Philippine bureaucracy has been beset with problems that need to be resolved to sustain a class of honest, accountable and responsible civil workers who deliver public service in the most effective and efficient way possible. Some challenges have adversely affected the bureaucracy so much that poor public service practices and negative bureaucratic behaviour have been embedded in Philippine culture and incorporated into its system of governance. Executive development intervention and the CES are responsible for their share of the challenges and problems in the bureaucracy.

\section{Failure to implement policies}

Unfortunately, some major policy reforms that would have strengthened the institution never gained ground. Policy proposals have been designed and advocated in the years since the reactivation of the CES in 1988, but most have been shelved due to a lack of political support. In 1993, the NCCESO began the arduous task of lobbying for the passage of a proposed bill strengthening the CES. The Association of ELP Alumni also consolidated its forces to push for the same bill. However, it never went further than committee-hearing level in both chambers of Parliament. A proposal to grant a significant premium to CESOs - which would have set a material difference between a CESO and non-CESO - suffered the same fate. The proposal was shot down early because of a lack of funding. The initiative to develop a mechanism for performance-based tenure started in 1989 but never

5 This section has been written with the assistance of 'A manifesto for the next government: A proposed Philippine Civil Service reform agenda', prepared by PA 208 Class (Philippine Administrative System) under Professor Alex Brillantes Jr UP National College of Public Administration and Governance, University of the Philippines, second semester, 2009-10. 
went beyond the proposal stage because it was considered unfeasible. Ambitious plans to establish a CES training centre or a CES college never got further than the drawing board.

The pieces of legislation governing the Philippine Civil Service remain scattered across different laws, decrees, letters of instruction and executive orders. The absence of a comprehensive civil service law has sometimes caused confusion among civil servants; many laws overlap and some have become obsolete.

\section{Politicisation of the bureaucracy}

Politicisation of the bureaucracy is an issue in the Philippines because civil service appointments continue to be made according to political pressure. This destroys the principle of merit, undermines security of tenure and demoralises career civil servants. Politicisation exists despite various programs designed to maintain high standards in the civil service by attracting the best and brightest leaders. Over the years, various presidents, particularly Macapagal-Arroyo, have exercised presidential privilege and circumvented the merit and fitness stages of civil service appointment by instating 10,000 civil service personnel-mostly in executive positions (David 2005). The prevailing culture of political patronage undermines the government's efforts to professionalise the bureaucracy and improve the capabilities of government workers to serve the public effectively and efficiently.

\section{Ethics and accountability in the Career Executive Service}

The issue of ethics and accountability in the CES continues to permeate the government and the bureaucracy on a massive scale despite the profusion of laws and the existence of numerous agencies designed to curb corruption. With good governance as the prevailing dictum in effective public administration, society now demands more accountability from civil servants in the performance of their duties. Never before in the history of its administrative system has Philippine society demanded as much accountability as it does today. Survey results indicating a very high public perception of corruption in the public sector as well as the ranking of the Philippines among the world's most corrupt countries seem to indicate that now more 
than ever civil servants are expected to tell the people truthfully how they have been performing their tasks. For instance, according to the Social Weather Stations (2010), the annual proportion of managers seeing 'a lot' of corruption in the public sector has been steady at twothirds since 2005. Almost all of them see it happening at the national level; progressively fewer see it at the provincial, city and barangay levels. In SWS 2015, a record-low 39 per cent say most companies in their sector of business give bribes to win public sector contracts (see Box 8.1 below). Accountability is seen as a key not only to good government but also to good governance.

\section{Box 8.1. Highlights of the SWS Survey on Corruption}

The survey found a record-low 39\% saying most (11\% almost all, $28 \%$ most) of the companies in their line of business give bribes to win public sector contracts, surpassing the previous record-low of $41 \%$ in 2012 and 2013

Of the 36 government institutions rated for sincerity in fighting corruption in the 2015 survey, 21 got favorable ratings, 9 neutral, and 6 unfavorable

The net ratings of sincerity (computed as \% sincere minus \% insincere) in fighting corruption was very good for the Securities and Exchange Commission (+63), Social Security System (+57), Philippine Stock Exchange (+55), Office of the President (+54), and Dept. of Trade and Industry $(+51)$

It was good for the Filipino business associations $(+49)$, Supreme Court $(+42)$, Civil Service Commission (+41), Dept. of Education (+43), Sandiganbayan (+37), Office of the Ombudsman (36), Commission on Audit (+36), and Dept. of Justice (+34)

It was moderate for Dept. of Health $(+28)$, Government Service Insurance System (+27), Dept. of Social Welfare and Development (+24), their own Barangay Government $(+19)$, Dept. of Finance (+15), Presidential Commission on Good Government $(+15)$, Governance Commission for GOCCs $(+12)$, and their own City Government $(+12)$

It was neutral for Dept. of Interior and Local Government $(+9)$, the Trial Courts (+6), Dept. of Environment and Natural Resources (+6), the Armed Forces of the Philippines (+4), Dept. of Budget and Management $(-7)$, Dept. of Transportation and Communication $(-2)$, the Senate $(-2)$, Bureau of Internal Revenue $(-4)$, and Commission on Elections (-6)

It was poor for Dept. of Agriculture (-10), Philippine National Police (-16), Dept. of Public Works and Highways (-21), House of Representatives (-25), and Land Transportation Office (-26)

It was very bad for Bureau of Customs at -55

Source: The 2014/15 SWS Survey of Enterprises on Corruption, www.sws.org.ph. 


\section{Public image and reputation}

Public service delivery continues to be a central criticism of the bureaucracy. Unfortunately, civil servants are generally viewed as incompetent, slow, rude and inefficient in rendering public service. They are viewed as influence peddlers and products of political accommodation and therefore do not possess the high degree of excellence, professionalism, intelligence and competence needed to be able to serve the public well.

Weak public service values are evident among government workers. They lack dedication and commitment in providing public service. It has been observed that the civil service has lost much of its service development orientation. Government service is no longer considered 'public service' but rather a job that public officials and employees need to support themselves and their families, forgetting that the public is the reason for the existence of the bureaucracy. That said, in spite of such a negative perception, we are aware that there are many gems in the bureaucracy - unheralded but dedicated public servants.

\section{Inadequate remuneration for CESOs}

Low compensation packages for executives (including low salaries) hinder the recruitment and retention of the best and brightest. The pay scale in the civil service does not compare with equivalent technical and supervisory positions in the private sector.

\section{Outdated systems and procedures}

Outdated systems and procedures are a problem in many agencies, resulting in inefficiency, as people in government are more concerned with adherence to rules than with the achievement of results and job productivity. The problem is exacerbated by the inability of agencies to keep up with the latest advances in information technology. 


\section{Recommendations}

Mindful of the need to address these issues and concerns urgently, implementing the following recommendations would contribute towards building executive capacity and transforming the Philippine bureaucracy into a model of excellent, reliable, efficient and desirable public service.

\section{Enact a Civil Service Code}

Codifying laws and relevant directives governing the civil service into a single, comprehensive statute (as sought by Senator Aquilino Pimentel Jr with Senate Bill Number 1162) would give the Philippine Civil Service system much-needed and long-awaited legal authority. Senators Panfilo Lacson and Jinggoy Estrada have filed other bills proposing the adoption of a Civil Service Code.

\section{Implement periodic evaluation of capacity-building programs}

\section{Enhance partnerships with non-governmental actors}

Cooperation should be encouraged between providers of executive training towards building capacity.

\section{Continue to recognise outstanding CESOs for their performance}

An example of recognition of CESO performance is the Gawad Civil Service (CES) ${ }^{6}$ - a motivational approach for CESOs to excel in the field of public service and good governance. This presidential award recognises CESOs for exemplary performance and significant contributions, particularly in the areas of innovation, information and communication technology, social services, administrative reforms and public policy. The search for worthy recipients aims to inspire members of the CES to live up to the ideals of the organization as well as recognize exceptional accomplishments to encourage consistent performance and to promote excellence among members of the

6 The Filipino term 'Gawad' means to give or confer or as a noun, it is an award. 
CES community. Gawad CES is open to all CES Officers and ThirdLevel Eligibles who are presidential appointees and are appointed to CES positions. The Gawad CES winner will receive a plaque with the Presidential Seal and Php100,000 cash reward.

Finally, the framework developed previously by the authors, and illustrated in Figure 8.1, may be considered in reforming public service for good governance. Capacity-building interventions may be targeted at all four areas of reform, but should pay special attention to changing the mindsets and behaviour of those in the public service, especially leaders and those occupying executive positions, as discussed in this chapter.

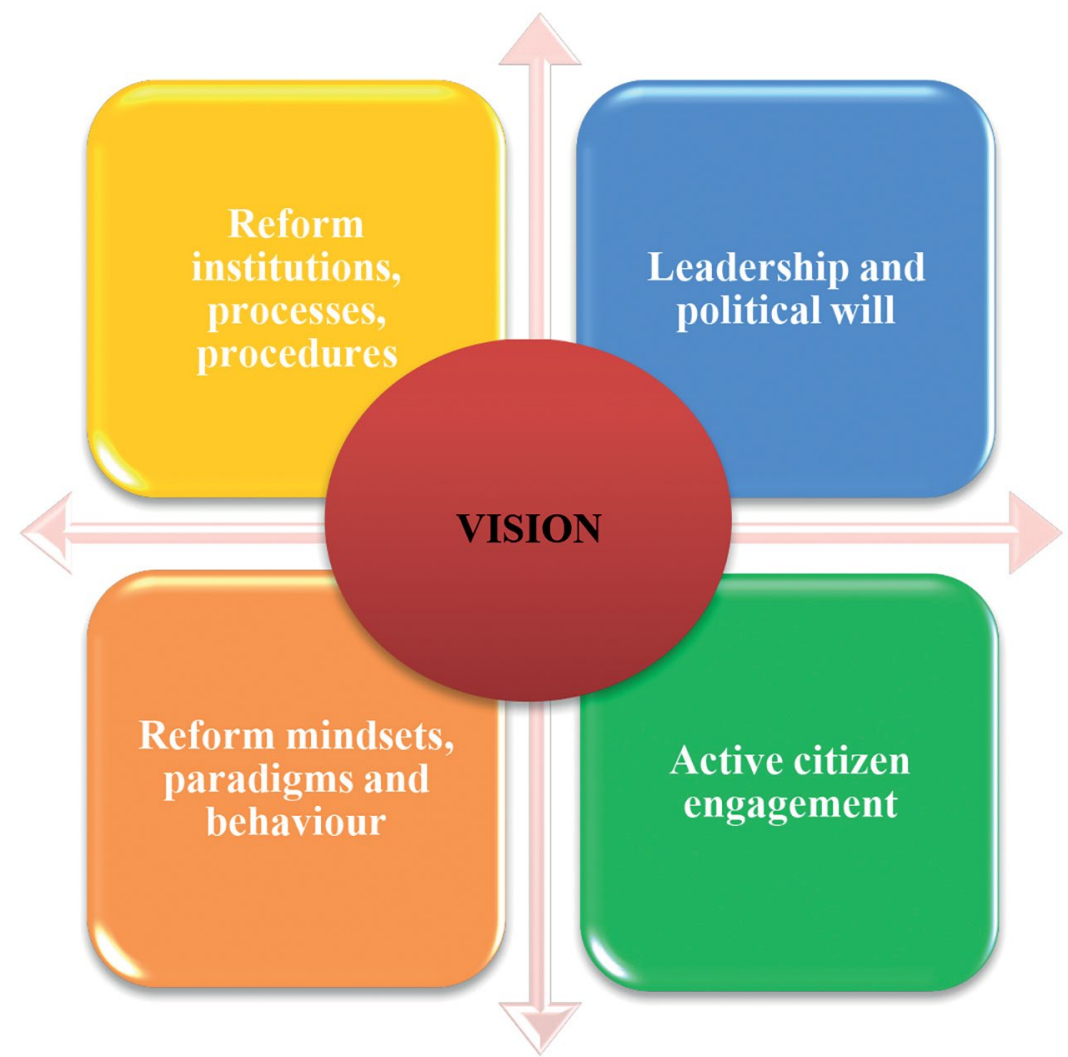

Figure 8.1: Reform framework for building executive capacity in the public sector for better governance

Source: Brillantes and Fernandez (2010). 
Indeed, building executive capacity is part of the overarching vision of reforming public administration for good governance. As indicated above, four elements are needed to achieve not only good governance (UNDP 1997) or 'good enough governance' (Grindle 2005), but also 'better governance':

1. reforming institutions, structures and processes

2. leadership

3. reforming behaviours and mindsets

4. citizen engagement.

\section{Conclusion}

Starting from a discussion of the historical context of the Philippine Civil Service, this chapter has discussed the various capacity-building programs available to CESOs. The primary strength of the Philippine CES is its members; the CESOs who have undergone the rigours of merit and fitness to serve in the bureaucracy. On the other hand, with identified challenges such as the politicisation of the Philippine bureaucracy, among other issues, there is a need to re-examine policy directions and standards, program values and priorities and procedures.

Capacity-building programs for the CES need to be reviewed to improve them. In this way, training programs, whether internally or externally provided, will be objectively evaluated in terms of their effectiveness, efficiency and even affordability. The CESB must continue its efforts to attract high-quality professional CESOs to work in the public service through adequate compensation packages. Aside from monetary or material rewards, the government should motivate the CES with awards for outstanding CESOs, such as the Gawad CES.

To maintain fairness and equality, the CESB should continue its informal regulatory function by defining how training providers are chosen. This will improve training programs in the future by eliminating poor training providers. The board must also continue to enhance its own regular training programs and look at how these can be improved. It is hoped that the recommendations made in this chapter will contribute to building executive capacity in the Philippines CES for public service for better governance. 
Indeed, as suggested earlier, one of the challenges of training is whether or not it has made an impact on the CES. The reform framework (Figure 8.1)-particularly developing leadership and reformed mindsets, paradigms and behaviour - is the ultimate objective of any training and capacity-building program. Reformed mindsets and behaviour, including those at the executive level, are essential for capacity-building programs to be truly effective and sustainable.

\section{References}

Bekke, H. A., Perry, J. L. and Toonen, T. A. (eds) 1996. Civil Service Systems in Comparative Perspective. Bloomington: Indiana Press.

Brillantes, A. B. and Fernandez, M. T. 2008. Is there a Philippines public administration? Or better still, for whom is Philippine public administration? Philippine Journal of Public Administration 52(2-4) (April-October): 55-80.

Brillantes, A. B. and Fernandez, M. T. 2009. Philippines. In P. S. Kim (ed.), Public Administration and Public Governance in ASEAN Member Countries and Korea. Seoul: Deayoung Moonhwasa Publishing Company, pp. 207-20.

Brillantes, A. B. and Fernandez, M. T. 2010. Toward a reform framework for good governance: Focus on anti-corruption. Philippine Journal of Public Administration 54(1-2): 87-127.

Career Executive Service Board (CESB) n.d. Career Executive Service Board. Available from: cesb.gov.ph (accessed 2015).

Career Executive Service Board (CESB) 2007. 2007 Annual Report. Quezon City: Career Executive Service Board.

Career Executive Service Board (CESB) 2009. 2009 Annual Report. Quezon City: Career Executive Service Board.

Career Executive Service Board (CESB) 2010. Dynamism Amidst Change: 2010 annual report. Quezon City: Career Executive Service Board.

Career Executive Service Board (CESB) 201la. The Public Manager 23(1) (January-March). 
Career Executive Service Board (CESB) 2011b. The Public Manager 3(4) (April).

Civil Service Commission (CSC) n.d. Civil Service Commission. Available from: csc.gov.ph (accessed 2015).

Condrey, S. E. and Maranto, R. 2001. Radical Reform of the Civil Service. Lanham, Md: Lexington Books.

David, K. 2005. Combating Corruption in the Philippines: Are we Plundering Our Chances or Doing it Better? Diliman Governance Forum Working Paper Series No. 2.

Grindle, M. S. 2005. Good enough governance revisited. A Report for DFID with reference to the Governance Target Strategy Paper, 2001. Cambridge, Mass.: Harvard University.

Hays, S. W. and Kearney, R. C. 2003. Public Personnel Administration: Problems and prospects. 4th edn. Upper Saddle River, NJ: Prentice Hall.

Hooton, C. G. 1997. Executive Governance: Presidential administrations and policy change in the federal bureaucracy. New York: M. E. Sharpe.

Lodevico, B. V. n.d. Thirty years: The story of the career executive service. Available from: oocities.org/vynkeziah/frontpagel.html (accessed 3 June 2014).

National Economic Development Authority (NEDA) 2011. Philippine Development Plan 2011-2016. Pasig City, Philippines: National Economic Development Authority.

Rhodes, R. and Weller, P. 2001. The Changing World of Top Officials: Mandarins or valets? Philadelphia: Open University Press.

Senate Bill No. 1162 2007. Civil Service Code. Proposed by Senator Aquilino Pimentel. 14th Session.

Smith, M. J. 1999. The Core Executive in Britain. London and New York: Macmillan \& St Martin's Press. 
Social Weather Station 2015. The 2014/15 SWS Survey of Enterprises on Corruption: Record-low $32 \%$ of executives have personal knowledge of corrupt transaction with government in the last 3 months. SWS: Quezon City. Available from: www.sws.org.ph.

Social Weather Station 2010. The 2010 SWS Survey of Enterprises on Corruption. SWS: Quezon City. Available from: www.sws.org.ph.

Stanton, T. 2001. Government Loans in L. Salamon, (ed.) Handbook of Policy Instruments. New York, Oxford University Press.

Stanton, T. H. and Ginsberg, B. 2004. Making Government Manageable: Executive organisation and management in the twenty-first century. Baltimore: Johns Hopkins University Press.

Theakston, K. 2000. Bureacracts and Leadership. London and New York: Macmillan \& St Martin's Press.

United Nations (UN) 2004. Role of Human Resources in Revitalising Public Administration: Report of the secretariat. New York: United Nations. Available from: unpanl.un.org/intradoc/groups/public/ documents/un/unpan014910.pdf.

United Nations Department of Economic and Social Affairs (UNDESA) 2005. Human Resources for Effective Public Administration in a Globalised World. New York: United Nations.

United Nations Development Programme 1997. Reconceptualizing Governance. Discussion Paper Series No. 2. New York. United Nations. 
This text is taken from Sharpening the Sword of State: Building executive capacities in the public services of the Asia-Pacific, edited by Andrew Podger and John Wanna, published 2016 by ANU Press, The Australian National University, Canberra, Australia. 